he is also engaged by the conflict of sharp jealousy over the time parents give to each other instead of to him. This becomes even more poignant when time, love, and attention are given to a new baby. As a first, eldest, and "only" he had all the time in the world from both parents. By the time he is 4 he may well be the eldest of three, with a single-handed mother and a hard-pressed father, themselves getting a bit frayed. So he fights back-for their attention, to remind them of his needs, and in resentment at the usurpation.

Something of this jealousy is inevitable, and preparing for it broadmindedly and with consideration does not alter that. Nevertheless, when hostility is shown to younger siblings it often causes a surprised anger in parents which may indeed lead to small evidences of rejection and mild recrimination. Obviously a child cannot be left to get away with murder, but restraining him has to be done with goodnatured firmness and humour. For if the bad child really is rejected, then his worst fears are coming true; it does not pay to grow up, he thinks, so let's go back to bedwetting and being fed, which in turn leads to crosser and more tired adults - in other words a vicious circle. Sometimes a few hours daily in nursery school (not all day in a day nursery) may go far to help tide over this difficult phase. The really important thing is to ensure that no love is lost while the child passes through it.

REFERENCE

1 Isaacs, S., The Nursery Years, 1932. Routledge, London.

\section{Paralytic Scoliosis}

Q. -What treatment is advised for a child with a paralytic scoliosis due to poliomyelitis? What is the prognosis? If the scoliosis is still mobile would a spinal support prevent deterioration?

A.-Paralytic scoliosis presents a complex problem, and only the simpler principles can be discussed here. The scoliosis is usually due to muscle imbalance. It is worth continuing active exercises for two years after the original attack of poliomyelitis, for, although this will not restore the balance, it may improve both sides in strength.

The prognosis depends on two main factors. The most important is the age at which the child contracted poliomyelitis; the earlier this occurred, the worse the prognosis. The other important factor is the degree of muscle imbalance ; the most important muscles from the point of view of the development of the scoliosis are the intercostals and the lateral flexors of the abdomen. Whether the curve is fixed or mobile is not very significant; a "postural " paralytic scoliosis is uncommon and usually only a temporary phase before the curve becomes fixed. Spinal supports of the ordinary type do not prevent the curvature of paralytic scoliosis increasing. They may have a place in holding up a flaccid trunk, but this is not strictly the problem of scoliosis. The Milwaukee brace devised by Blount is the only spinal support of value, and this could be expected to maintain the curve at its present level probably for a number of years.

\section{Treatment of Manic-Depressive Psychoses}

Q. -What recent advances have there been in the treatment of manic-depressive psychoses? Are any of the new tranquillizers helpful, either alone or combined with electro-convulsive therapy, and, if so, what regime is advised?

A.- There have been no outstanding recent advances in the treatment of manic-depressive psychoses. Electroconvulsive therapy is helpful in the depressive phase, but often it is useful only towards the end of the phase ; it may be much less effective at the beginning of an attack. Electroconvulsive therapy is also less useful in the manic phase, though here too it may help to damp down the severity of the symptoms. The new chemical tranquillizers are also not outstandingly helpful in terminating an attack of depression or mania, though they can modify some of the symptoms ; for instance, in the depressive phase the patient does not necessarily become less depressed, but he can sometimes be made less agitated and worried about his depressive symptoms. Very large doses of the tranquillizers may be needed to combat the manic phase, and even then symptoms are only modified rather than abolished.

Recently evidence has been accumulating to suggest that lithium salts can be helpful in the treatment of the manic phase. ${ }^{1}$ Lithium carbonate may be used in doses of around $0.6 \mathrm{~g}$. three to four times a day for the first 7-10 days; subsequently the dose is gradually reduced, if improvement occurs, to a maintenance dose of $0.6 \mathrm{~g}$. daily. The drug is given on six days in the week and omitted on the seventh to help its elimination. Unpleasant side-effects can occur which disappear if the drug is withheld. The drug can be continued for weeks or months if necessary.

$$
\text { REFERENCE }
$$

1 Rice, D., J. ment. Sci., 1956, 102, 604.

\section{Wassermann in Weil's Disease}

Q. - I have read that the Wassermann reaction is positive in case of Weil's disease. If this is true, how can a positive Wassermann due to syphilis be distinguished from one due to Weil's disease?

A.-Earle Moore ${ }^{1}$ reports that positive serum tests for syphilis are obtained in cases of Weil's disease. Positive reactions can be differentiated as true or non-treponemal reactions by means of a treponemal immobilization test.

\section{REFERENCE}

1 Moore, J. E., J. vener. Dis. Inform., 1949, Suppl. No. 23, p. 55.

\section{NOTES AND COMMENTS}

Infirmary Mice.-THE INQUIRER writes: I am intrigued by Dr. W. Lane-Petter's comments ("Notes and Comments," December 1, p. 1318), which, of course, we should have thought of ourselves. I have now made inquiries of the hospital from which the story first came ("Any Questions ?" November 17, p. 1190), and discover that it is still free from vermin, it still has its television sets, but over the last year it has had a considerable number of cases of so-called dysentery, possibly not of notifiable type. I do not know what bacteriological investigations were undertaken. The moral of this whole little story would seem to be that, if a hospital loses its mice, this should not necessarily be attributed to the acquisition of television sets: it may in fact be an indication to the bacteriologist to take steps.

Correction.-We regret that Dr. Cécile Asher's name was misspelt in the Journal of December 8, p. 1353.

Books of "Any Questions ?" and Refresher Course Articles.The following books are available through booksellers or from the Publishing Manager, B.M.A. House. Prices include postage. Any Questions?, Volumes 2 and 3 (8s. each); Refresher Course for General Practitioners, Volumes 2 and 3 (26s. 6d. each inland, 26s. overseas); Clinical Pathology in General Practice (22s. 3d. inland, $21 \mathrm{~s}$. $9 \mathrm{~d}$. overseas).

All communications with regard to editorial business should be addressed to THE EDITOR, BrITISH MEDICAL JOURNAL B.M. House, TAVISTOCK SQUARE SQUAR, LONDN, W. Aitiology, Westcent, London. ORIGINAL ARTICLES AND LETTERS forwarded for publication are understood to be offer

Medical Journal alone unless the contrary be stated.
Authors desiring REPRINTS should communicate with the Publishing

Authors desiring REPRINTS should communicate with the Publishing
Manager, B.M.A. House, Tavistock Square, W.C.1, on receipt of proofs. Manager, B.M.A. House, Tavistock Square, W.C.1, on receipt of proofs.
Authors overseas should indicate on MSS. if reprints are required, as Authors overseas should indica

proofs are not sent abroad.
ADVERTISEMENTS should be addressed to the Advertisement Director. B.M.A House, Tavistock Square, London, W.C.1 (hours 9 a.m. to 5 p.m.). TELEPHONE: EUSTON 4499. Telegrams: Britmedads, Westcent, London. MEMBERS' SUBSCRIPTIONS should be sent to the SECRETARY of the Association. TelephONE: EUSTON 4499. Telegrams: Medisecra, Westcent, London.

B.M.A. Scotrish Office: 7, Drumsheugh Gardens, Edinburgh. 